\title{
CRYOPRESERVATION OF SPERM OF LABEO ROHITA (HAMILTON, 1822) AND ITS USE IN FERTILIZATION AND HATCHING OF EGGS
}

\author{
M. R. I. Sarder*, A. K. M. A. Rahman, M. S. Samad, K. M. S. Nazrul \\ and M. K. J. Bhuiyan' \\ Department of Fisheries Biology and Genetics, Bangladesh Agricultural University \\ Mymensingh-2202, Bangladesh
}

\begin{abstract}
Cryopreservation is one of the widely accepted and useful methods for preservation of gamete especially the spermatozoa. Experiments were conducted to develop the protocols for cryopreservation of sperm of Labeo rohita and to assess the effect of cryopreserved sperm on fertilization and hatching. Six extenders Alsever's solution, egg-yolk citrate, urea egg-yolk, Kurokura-2, $\mathrm{M}^{\mathrm{a}}$ and $\mathrm{M}^{\mathrm{b}}$ and five cryoprotectants ethanol, methanol, DMSO, DMA and glycerol were employed. Diluents were prepared by mixing the cryoprotectants at $10 \%$ concentration of the extenders $(\% \mathrm{v} / \mathrm{v})$. Milt and diluents were mixed at a ratio of 1:9 for Alsever's solution and Kurokura-2; and 1:4 for urea egg-yolk, egg-yolk citrate, $\mathrm{M}^{\mathrm{a}}$ and $\mathrm{M}^{\mathrm{b}}$. Egg-yolk citrate with $10 \%$ DMSO showed best performance producing $85 \pm 1.6 \%$ post-thaw motility followed by $83 \pm 2 \%$ and $81 \pm 2.9 \%$ with Alsever's solution and urea egg-yolk respectively. Other extenders did not produce satisfactory results. Milt was diluted at six ratios (1:2, 1:4, 1:7, 1:9, 1:15 and 1:20) and 1:4 dilution showed the highest post-thaw motility for egg-yolk citrate and urea egg-yolk and 1:9 for Alsever's solution. Six cryoprotectant concentrations $(5,7,10,15,20 \%$ and $30 \%)$ were investigated and $10 \%$ concentration produced the highest post-thaw motility. In breeding trials, sperm preserved with egg-yolk citrate plus DMSO as well as Alsever's solution plus DMSO fertilized eggs and produced hatchlings. The fertilization and hatching rates were $57 \pm 7 \%$ and $46.5 \pm 3.5 \%$ for egg-yolk citrate, and $33.5 \pm 3.5 \%$ and $27 \pm 3 \%$ for Alsever's solution respectively. Fresh sperm yielded $76 \pm 4 \%$ fertilization and $70.5 \pm 5.5 \%$ hatching. The protocol developed through this study can be applied for long-term conservation of genetic materials of $L$. rohita and the cryopreserved sperm can be used in artificial breeding for generating new individuals.
\end{abstract}

Key Words: Labeo rohita, Spermatozoa, Cryopreservation, Fertilization, Hatching

\footnotetext{
1 Department of Agricultural Statistics, Bangladesh Agricultural University, Mymensingh-2202, Bangladesh

*Corresponding author: rafiqulsarder@yahoo.com
} 


\section{INTRODUCTION}

Labeo rohita locally known as rohu is one of the important aquaculture candidates of Indian major carps. It is distributed in freshwaters of Sindhu and Punjab (Pakistan), through India, Assam, Bangladesh and Burma (Day, 1878). According to FAO (2005), the distribution of the rohu has also extended to the Philippines, former USSR, Japan, Sri Lanka, Laos, Pakistan, Malaysia, Thailand, Vietnam, Madagascar, China and Mauritius.

Production of seed of Indian major carps through artificial breeding techniques has begun in the government hatcheries during 1970's. In 1980's many fish hatcheries both in government and private sectors were established and the breeding techniques have been expanded. At present about 119 government and 931 private hatcheries are being operated in Bangladesh and produced more than 99\% of the total seed (DoF, 2011). The seed produced in hatcheries is enough to meet the demand of farmers but the quality of seed has been deteriorated over the years specially in private hatcheries. The main reasons are small number of brood stock, improper brood stock management and breeding practice in the hatchery (Hansen et al., 2006). Many hatcheries start their production with a small founder stock and used the broods for many generations with a replacement from the succeeding generations. Thus, the hatchery carps virtually become closed to genetic exchange with wild stocks (Eknath and Doyle, 1990). As a result, mating takes place among closely related individuals which causes inbreeding. This practice also causes genetic drift in the population by eliminating many alleles. If any planned breeding program is not initiated in these cases, inbreeding and genetic drift may ruin the population.

L. rohita is the first ranking fish in aquaculture due to its relatively better taste and higher market price. It constitutes nearly $23 \%$ of the total fish production through aquaculture (Alam, 2002). Besides inbreeding and genetic drift, inter-specific hybridization is taking place in many hatcheries due to shortage of broods or unintentional breeding practice. These hybrids are being stocked in grow-out ponds and could escape to open water bodies through flooding. There is a wide spread concern that if such hybrids escape in the natural water bodies it might cause genetic introgression and results in difficulty to distinguish them from the pure species. It is therefore urgent to save the brood stocks from the hazards and maintain their purity. Breeding programs using cryopreserved sperm of the base population instead of male sires every few generations could be used in combination with hatchery practices to minimize the deterioration of genetic quality. The present study was designed to develop the protocols for cryopreservation of sperm of $L$. rohita. Cryopreservation deals with cryobiology that relates to long-term preservation and storage of biological materials at very low temperature, usually at $-196^{\circ} \mathrm{C}$. At this low temperature, cellular viability can be stored in a genetically stable form (Ashwood-Smith, 1980). The specific objectives of the study were to determine the suitable extenders and cryoprotectants, milt dilution ratio, cryoprotectant concentration and fertilizing capability of cryopreserved sperm. 


\section{MATERIALS AND METHODS}

\section{Collection and rearing of broodstock}

Representative numbers of mature brood fish of L. rohita were collected from different sources (Halda river origin and from different government hatcheries) and stocked in the ponds located in the northern side of the Fisheries Faculty Building, Bangladesh Agricultural University, Mymensingh. The weight of the individuals ranged from 2 to 4 $\mathrm{kg}$. Fish were reared with supplementary feed consisting of mustard oil cake, rice bran, wheat bran, and fish meal at the rate of $30 \%, 30 \%, 30 \%$ and $10 \%$ respectively. Required amount of Megavit-aqua (vitamin-mineral-amino acid premix) was supplemented with the feed to enhance the gonadal development of fish. The feed was administered twice daily at the rate of $4-5 \%$ of the body weight. Organic (cow dung) and inorganic (urea and phosphate) fertilizers were also applied at a rate of $2 \mathrm{~kg} / \mathrm{dec}$ and $150 \mathrm{~g} / \mathrm{dec}$ respectively, at 15 days interval to increase the natural food production of the pond. Regular adding of underground water, liming $(250 \mathrm{~g} / \mathrm{dec} / \mathrm{month})$, checking of fish health and water quality monitoring were also done during the experimental period.

\section{Collection of sperm and checking its motility}

Male and female brood fish were collected from rearing ponds and kept in cisterns in the hatchery for acclimatization through proper showering and aeration. After $6 \mathrm{hr}$ of conditioning, both male and female fish were induced with pituitary gland (PG) extract, where females received two injections with a dose $2 \mathrm{mg} / \mathrm{kg}$ body weight as first injection and $5-6 \mathrm{mg} / \mathrm{kg}$ body weight as the second. Males received only a single PG hormone injection with a dose of $2 \mathrm{mg} / \mathrm{kg}$ body weight. Sperm was collected from the induced male fish through stripping in a $5 \mathrm{ml}$ glass tube without any contamination. Collected milt was kept on ice. One to $2 \mu \mathrm{l}$ of sperm was placed on a glass slide and $100 \mu \mathrm{l}$ of distilled water was added to activate the sperm. The motility of the activated sperm was observed using a compound microscope at $\times 10$ or $\times 40$ magnification. The motility was expressed as the percentage of sperm which had active rotatory movement.

\section{Experiment I: Selection of suitable combination of extender and cryoprotectant}

To determine the suitable combination of extenders and cryoprotectants, six extenders Alsever's solution, egg-yolk citrate, urea egg-yolk, Kurokura-2, $\mathrm{M}^{\mathrm{a}}$ and $\mathrm{M}^{\mathrm{b}}$ solutions and five cryoprotectants methanol, ethanol, DMSO, DMA, and glycerol were used. The chemical constituents of these extenders are given in Table 1. Diluents (extender + cryoprotectant) were prepared by adding $10 \%$ cryoprotectant to $90 \%$ extender ( $\% \mathrm{v} / \mathrm{v}$ ). For egg-yolk citrate, urea egg-yolk, $\mathrm{M}^{\mathrm{a}}$ and $\mathrm{M}^{\mathrm{b}}$ milt samples were diluted at the ratio of 1 : 4 (milt : diluents) while 1:9 dilution ratio was maintained for Alsever's and Kurokura-2 solutions. The dilution ratios between diluent and milt, and the cryoprotectant concentration were chosen from previous studies (Kumar 1988 \& 1989; Sarder et al., 2009; Magyary et al., 2000 and Hossain and Sarder, 2009). 
Table 1. Chemical constituents of different extenders used for cryopreservation of sperm of L. rohita

\begin{tabular}{|c|c|c|c|c|c|c|}
\hline Extender & I & II & III & IV & $\mathrm{V}$ & VIII \\
\hline Constituents & $\mathrm{M}_{\mathrm{a}}$ & $\mathrm{M}_{\mathrm{b}}$ & Kurokura-2 & $\begin{array}{l}\text { Alsever's } \\
\text { solution }\end{array}$ & Egg-yolk citrate & $\begin{array}{l}\text { Urea-egg- } \\
\text { yolk }\end{array}$ \\
\hline Sodium chloride & $730 \mathrm{mg}$ & $850 \mathrm{mg}$ & $360 \mathrm{mg}$ & $0.4 \%$ & $0.4 \%$ & $0.3 \%$ \\
\hline Urea & - & - & - & - & - & $0.4 \%$ \\
\hline Sodium citrate & - & - & - & $0.8 \%$ & $0.3 \%$ & - \\
\hline Sodium bicarbonate & $500 \mathrm{mg}$ & $500 \mathrm{mg}$ & $20 \mathrm{mg}$ & - & \multirow{7}{*}{\multicolumn{2}{|c|}{$\begin{array}{l}\text { Dissolved in } 100 \mathrm{ml} \text { of distilled } \\
\text { water. Pancromycin }(1000 \\
\mathrm{iu} / \mathrm{ml}) \text { and streptomycin }(1000 \\
\mathrm{iu} / \mathrm{ml}) \text { were added to the } \\
\text { buffer solution. Egg yolk was } \\
\text { added to the buffer at a ratio of } \\
1: 4 \quad \text { (egg yolk: buffer). } \\
\text { Therefore, } 80 \mathrm{ml} \text { of buffer was } \\
\text { mixed with } 20 \mathrm{ml} \text { of egg yolk. }\end{array}$}} \\
\hline Fructose & $500 \mathrm{mg}$ & - & - & - & & \\
\hline Mannitol & $500 \mathrm{mg}$ & - & - & - & & \\
\hline $\mathrm{CaCl}_{2}$ & - & - & $22 \mathrm{mg}$ & - & & \\
\hline $\mathrm{KCl}$ & - & - & $1000 \mathrm{mg}$ & - & & \\
\hline $\mathrm{MgCl}_{2}$ & - & - & $8 \mathrm{mg}$ & - & & \\
\hline Vegetable lecithin & \multicolumn{3}{|c|}{$\begin{array}{c}\text { Dissolved in } 100 \mathrm{ml} \text { distilled } \\
\text { water }\end{array}$} & - & & \\
\hline
\end{tabular}

\section{Milt preparation and freezing}

Milt samples were mixed with diluents and kept on ice before drawn into French straws. The milt was equilibrated for $10 \mathrm{~min}$ and during equilibration it was drawn into $250 \mu \mathrm{l}$ French straw using a micropipette. The free ends of the straws were sealed manually using a heated crucible tongs. The straws were placed into the cryochamber and cooled using a computer controlled-rate freezer (CL-3300, equipped with the software Cryogenesis, version 4, for Windows, Cryologic, Pty Ltd., Australia, 1998 and 1999). Twostep freezing protocol was used where sample was first cooled to $-4^{\circ} \mathrm{C}$ at a temperature decreasing rate of $4^{\circ} \mathrm{C}$ per min, and then to $-80^{\circ} \mathrm{C}$ at $10^{\circ} \mathrm{C}$ per min. After freezing samples were removed from the cryochamber and loaded in the canisters and placed into the liquid nitrogen $\left(-196^{\circ} \mathrm{C}\right)$ for $24-48 \mathrm{~h}$. The post-thaw motility of the sperm was checked by thawing the sperm at room temperature $\left(25-26^{\circ} \mathrm{C}\right)$ for about $1 \mathrm{~min}$. The straws were cut near the cotton plug end and 1 to $2 \mu \mathrm{l}$ of milt was placed on to a glass slide, activated the sperm by adding 100-150 $\mu 1$ of distilled water and assessed the motility under microscope (eye estimation).

\section{Experiment II: Selection of milt and diluent ratio}

To determine the suitable dilution ratio between milt and diluent, three extenders, Alsever's solution, egg-yolk citrate and urea egg-yolk and four cryoprotectants, ethanol, methanol, DMSO and DMA were used. The extenders and cryoprotectants were chosen by observing their performance in experiment I. Milt was diluted with those diluents at six different ratios 1:2, 1:4, 1:7, 1:9, 1:15, and 1:20 and thereby, twenty four combinations were obtained for each extender. The dilution ratios were chosen from the previous work of Indian major carps (Sarder, 2004). The post-thaw motility of the sperm at different ratios was assessed and motility was recorded. 


\section{Experiment-III: Selection of cryoprotectant concentration}

To determine the suitable cryoprotectant concentration in the diluents, four cryoprotectants (ethanol, methanol, DMSO and DMA) were mixed with three extenders (Alsever's solution, egg-yolk citrate and urea egg-yolk) at five different concentrations such as $5,7,10,15,20 \%$ and $30 \%$. Twenty different diluents were generated from each extender. Post-thaw motility of sperm preserved at different cryoprotectant concentrations was assessed and motility was recorded.

\section{Experiment-IV: Effects of cryopreserved spermatozoa on fertilization and hatching rates:}

Two breeding trials were conducted to find out the effects of cryopreserved sperm on fertilization and hatching rates of eggs. Three extenders Alsever's solution, egg-yolk citrate and urea egg-yolk and four cryoprotectants ethanol, methanol, DMSO and DMA were used for breeding trials. Both hatching jars and bowls were used for incubation of eggs. Stripped eggs were divided into eight batches where each batch contained approximately 800 eggs. Six batches of eggs were fertilized with sperm preserved with three different diluents, i.e. each diluent had two replicates, and two batches of eggs were fertilized with fresh sperm as control. The frozen straws, after thawing at room temperature for $1 \mathrm{~min}$, were cut at both ends and mixed with eggs. Each batch of eggs was fertilized with $10 \times 230 \mu$ l of cryopreserved milt where each straw contained $230 \mu$ l diluted milt. For control, adequate amount of fresh milt was used. The egg-sperm mass was mixed using a clean feather and during mixing some tap water was added. The mixer was washed carefully 3 to 4 times with tap water and transferred to the previously marked incubation jars and bowls. The incubators were connected with supply water through plastic pipe for continuous movement of the eggs. After 6 hours of fertilization, some eggs were collected from all jars (eggs fertilized with cryopreserved sperm and fresh sperm) and observed the progress of cell division using microscope. The fertilized eggs looked clear and transparent while unfertilized eggs looked opaque and the nucleus was white. After 18-24h of fertilization eggs were hatched out, hatchlings were counted and transferred to the plastic bowls for rearing.

\section{Statistical analyses}

Data of the experiments I, II and III were presented as percentage of motile cells. The effects of different extenders and cryoprotectants on equilibration and post-thaw motility of sperm, dilution ratios and cryoprotectant concentrations were analyzed using twofactor randomized block design through computer software package (MSTAT). Means were separated by Least Significant Difference (LSD) Test and DMRT at 1\% and 5\% level of significance. The effects of cryopreserved sperm on fertilization and hatching were analyzed using paired $t$-Test.

\section{Experiment I}

\section{RESULTS}

Six extenders and five cryoprotectants were used for selecting suitable diluent. The equilibration motility of sperm in Alsever's solution, urea egg-yolk and egg-yolk citrate 
was between $75-90 \%$ with all the cryoprotectants but the equilibration motility was not satisfactory with other three extenders Kurokura-2, $\mathrm{M}^{\mathrm{a}}$ and $\mathrm{M}^{\mathrm{b}}$ (0 to 60\%). The post-thaw motility was considerably reduced in all the diluents including the first three ones. Eggyolk citrate, Alsever's solution and urea egg-yolk with DMSO performed best producing $>80 \%$ post-thaw motility. Egg-yolk citrate with ethanol also produced $>80 \%$ post-thaw motility (Table 2). Methanol and DMA with urea egg-yolk, egg-yolk citrate and Alsever's solution produced moderate post-thaw motility ranging $65 \%$ to $75 \%$. Kurokura-2, $\mathrm{M}^{\mathrm{a}}$ and $\mathrm{M}^{\mathrm{b}}$ with all the cryoprotectants produced very poor post-thaw motility ranging $0-31 \%$ (Table 2). Glycerol as a cryoprotectant produced the worst results with all the extenders and in many cases the sample became clotted. Statistical analysis showed that there were significant effects $(\mathrm{P}<0.05)$ of all the extenders and cryoprotectants and their combinations on equilibration and post-thaw motility of sperm. Duncan's Multiple Range Test revealed that DMSO with Alsever's solution, egg-yolk citrate and urea egg-yolk to be the suitable diluents for preservation of sperm (Table 2).

\section{Experiment II}

The effects of various dilution ratios of milt on post-thaw motility are presented in Fig. 1a-c. Milt diluted at 1:4 ratio showed the highest post-thaw motility with egg-yolk citrate $(>75 \%$ motility). Highest post-thaw motility $(>58 \%)$ was obtained from $1: 9$ in Alsever's solution. DMSO was found more effective than other cryoprotectants with eggyolk citrate, urea egg-yolk and Alsever's solution at 1:4, 1:4 and 1:9 dilution ratios respectively (Figs. 1a-c). The post-thaw motility of sperm at 1:4 dilution was significantly $(\mathrm{P}<0.01)$ higher than that of other dilutions for egg-yolk citrate and urea egg-yolk. In Alsever's solution 1:9 dilution ratio produced significantly $(\mathrm{P}<0.01)$ higher post-thaw motility than others. The extremely low and high dilutions, for example, 1:2, 1:15 and 1:20 yielded poor motility in few cases (Fig. 1a-c).

\section{Experiment III}

Cryoprotectants with six concentrations $(5 \%, 7 \%, 10 \%, 15 \%, 20 \%$ and $30 \%)$ were trialed with the extenders and found that $10 \%$ cryoprotectants produced highest post-thaw motility followed by 15\% and 7\% concentrations (Fig. 2a-c). Egg-yolk citrate with both DMSO and methanol (10\%), urea egg-yolk and Alsever's solution with 10\% DMSO produced the highest post-thaw motility $(>80 \%)$. Other cryoprotectants at $10 \%$ concentrations produced $70-75 \%$ post-thaw motility. Further increase $(15 \%)$ or decrease $(7 \%)$ of cryoprotectant concentration reduced the motility of sperm. $30 \%$ concentration yielded the worst result and seemed toxic to sperm.

\section{Experiment IV}

Eggs were fertilized with cryopreserved sperm as well as with fresh sperm. Sperm preserved with diluents composed of three extenders and four cryoprotectants were used for fertilization but only two diluents responded positively. Egg-yolk citrate plus DMSO produced the highest fertilization $(57 \pm 7 \%)$ and hatching $(46.5 \pm 3.5 \%)$, while $33.5 \pm 3.5 \%$ and $27 \pm 3 \%$ fertilization and hatching were obtained from those preserved with Alsever's solution plus DMSO respectively. Fresh sperm used as control yielded $76 \pm 4 \%$ and $70.5 \pm$ 
$5.5 \%$ fertilization and hatching respectively (Fig. 3). The breeding efficiency of cryopreserved sperm preserved with two diluents was compared and a significant variation was found for hatching $(\mathrm{P} \leq 0.05)$ and not for fertilization $(\mathrm{P} \leq 0.095)$. No statistical comparison was made between the breeding performance of fresh and cryopreserved sperm as the concentration of fresh and cryopreserved sperm was not standardized.

Table 2. Effects of different combinations of extenders and cryoprotectants on the equilibration and post-thaw motility of sperm of L. rohita

\begin{tabular}{|c|c|c|c|}
\hline \multicolumn{2}{|r|}{ Diluents } & \multicolumn{2}{|c|}{ Motility of sperm (\%) } \\
\hline Extenders & Cryoprotectants (10\%) & Equilibration motility & Post-thaw motility \\
\hline \multirow{5}{*}{$\begin{array}{l}\text { Alsever's } \\
\text { solution }\end{array}$} & Ethanol & $84 \pm 0 \mathrm{a}$ & $62 \pm 3.7 \mathrm{e}$ \\
\hline & Methanol & $83 \pm 1.2^{a}$ & $68 \pm 3.7$ cde \\
\hline & DMSO & $90 \pm 3.5^{a}$ & $83 \pm 2^{a b}$ \\
\hline & DMA & $81 \pm 1.9 \mathrm{a}$ & $73 \pm 3.7$ abcde \\
\hline & Glycerol & $74 \pm 1.9 \mathrm{a}$ & $0 \mathrm{~g}$ \\
\hline \multirow{5}{*}{$\begin{array}{l}\text { Egg-yolk } \\
\text { citrate }\end{array}$} & Ethanol & $89 \pm 2.4^{a}$ & $82 \pm 1.2^{\mathrm{abc}}$ \\
\hline & Methanol & $79 \pm 1.9 \mathrm{a}$ & $70 \pm 1^{\text {bcde }}$ \\
\hline & DMSO & $90 \pm 2.2^{a}$ & $85 \pm 1.6^{a}$ \\
\hline & DMA & $79 \pm 1.9 \mathrm{a}$ & $68 \pm 3.7$ cde \\
\hline & Glycerol & $81 \pm 1^{\mathrm{a}}$ & $66 \pm 8.3 \mathrm{de}$ \\
\hline \multirow[t]{5}{*}{ Urea-egg yolk } & Ethanol & $81 \pm 1^{a}$ & $75 \pm 4.5^{\text {abcde }}$ \\
\hline & Methanol & $81 \pm 1^{\mathrm{a}}$ & $75 \pm 2.2^{\mathrm{abcde}}$ \\
\hline & DMSO & $83 \pm 2^{a}$ & $81 \pm 2.9 \mathrm{abc}$ \\
\hline & DMA & $79 \pm 2.4^{a}$ & $74 \pm 2.4^{\text {abcde }}$ \\
\hline & Glycerol & $79 \pm 1.9^{a}$ & $77 \pm 3.4^{\mathrm{abcd}}$ \\
\hline \multirow[t]{5}{*}{ Kurokura-2 } & Ethanol & $39 \pm 14.2^{c}$ & $19 \pm 10.0^{\mathrm{f}}$ \\
\hline & Methanol & $45 \pm 12.4^{b c}$ & $6 \pm 2.4 g$ \\
\hline & DMSO & $59 \pm 12.1^{b}$ & $31 \pm 13.1^{\mathrm{f}}$ \\
\hline & DMA & $46 \pm 7.5^{b c}$ & $22 \pm 9.7^{f}$ \\
\hline & Glycerol & $38 \pm 11.0^{c}$ & $0 \mathrm{~g}$ \\
\hline \multirow[t]{5}{*}{$\mathrm{M}^{\mathrm{a}}$} & Ethanol & $14 \pm 6.8^{\mathrm{de}}$ & $4 \pm 2.4 \mathrm{~g}$ \\
\hline & Methanol & $12 \pm 5.8^{\mathrm{de}}$ & $1 \pm 1 \mathrm{~g}$ \\
\hline & DMSO & $18 \pm 8^{\mathrm{d}}$ & $2 \pm 2 \mathrm{~g}$ \\
\hline & DMA & $10 \pm 4.5^{\mathrm{de}}$ & $2 \pm 2 g$ \\
\hline & Glycerol & $10 \pm 4.5^{\mathrm{de}}$ & $0 \mathrm{~g}$ \\
\hline \multirow[t]{5}{*}{$\overline{\mathrm{M}^{\mathrm{b}}}$} & Ethanol & $0^{\mathrm{e}}$ & $0 \mathrm{~g}$ \\
\hline & Methanol & $2 \pm 2^{\mathrm{de}}$ & $1 \pm 1 \mathrm{~g}$ \\
\hline & DMSO & $2 \pm 2^{\mathrm{de}}$ & $0 \mathrm{~g}$ \\
\hline & DMA & $6 \pm 4^{\mathrm{de}}$ & $0 \mathrm{~g}$ \\
\hline & Glycerol & $2 \pm 2^{\text {de }}$ & $0 \mathrm{~g}$ \\
\hline
\end{tabular}

Note: Means in column with same superscripts indicate no significant variation; Means \pm S.E 

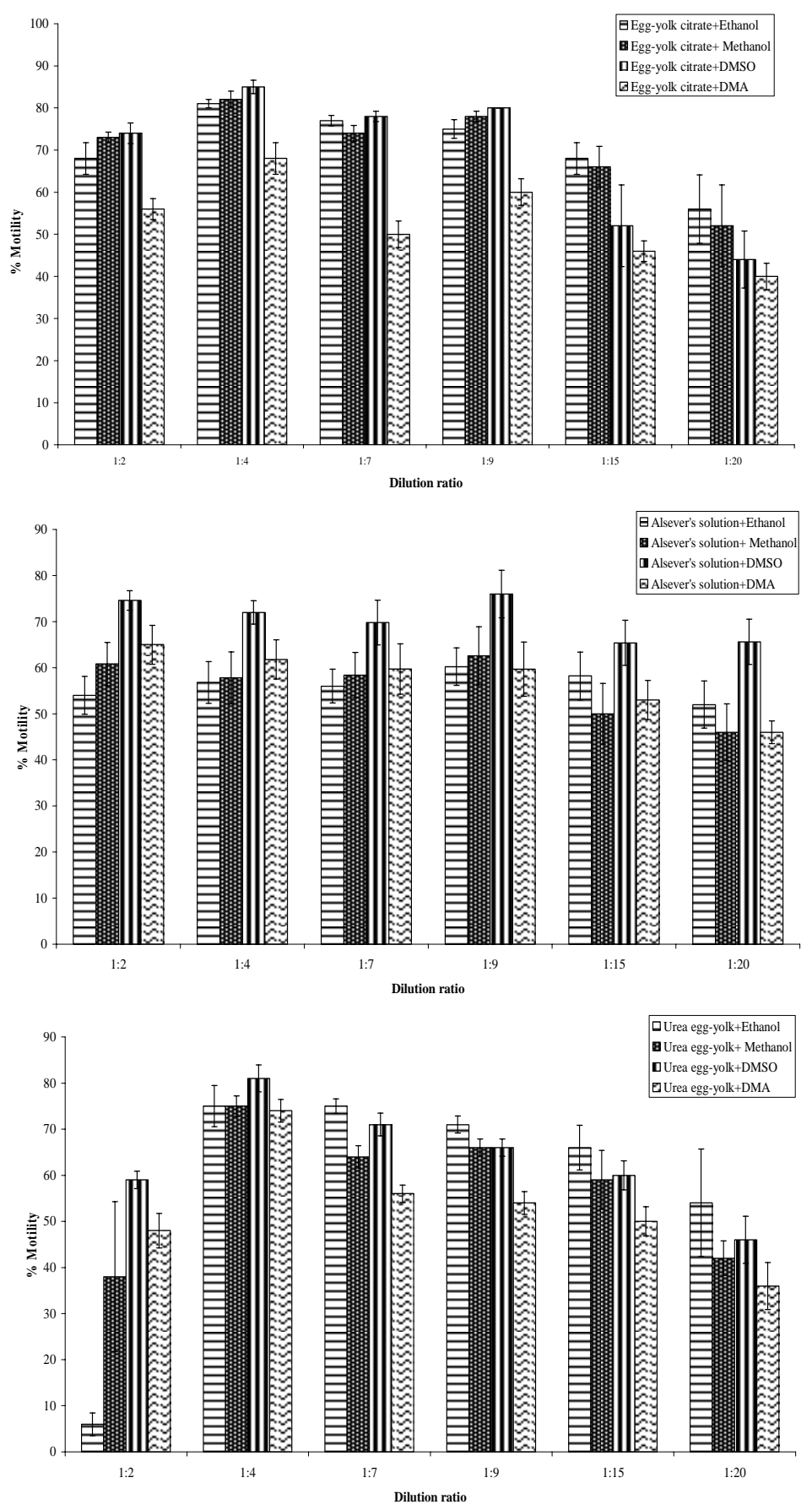

Fig. 1 a-c. The effects of dilution ratio (milt: diluent) on post- thaw motility of sperm of L. rohita. Milt diluted with (a) egg-yolk citrate (b) Alsever's solution and (c) urea egg-yolk 

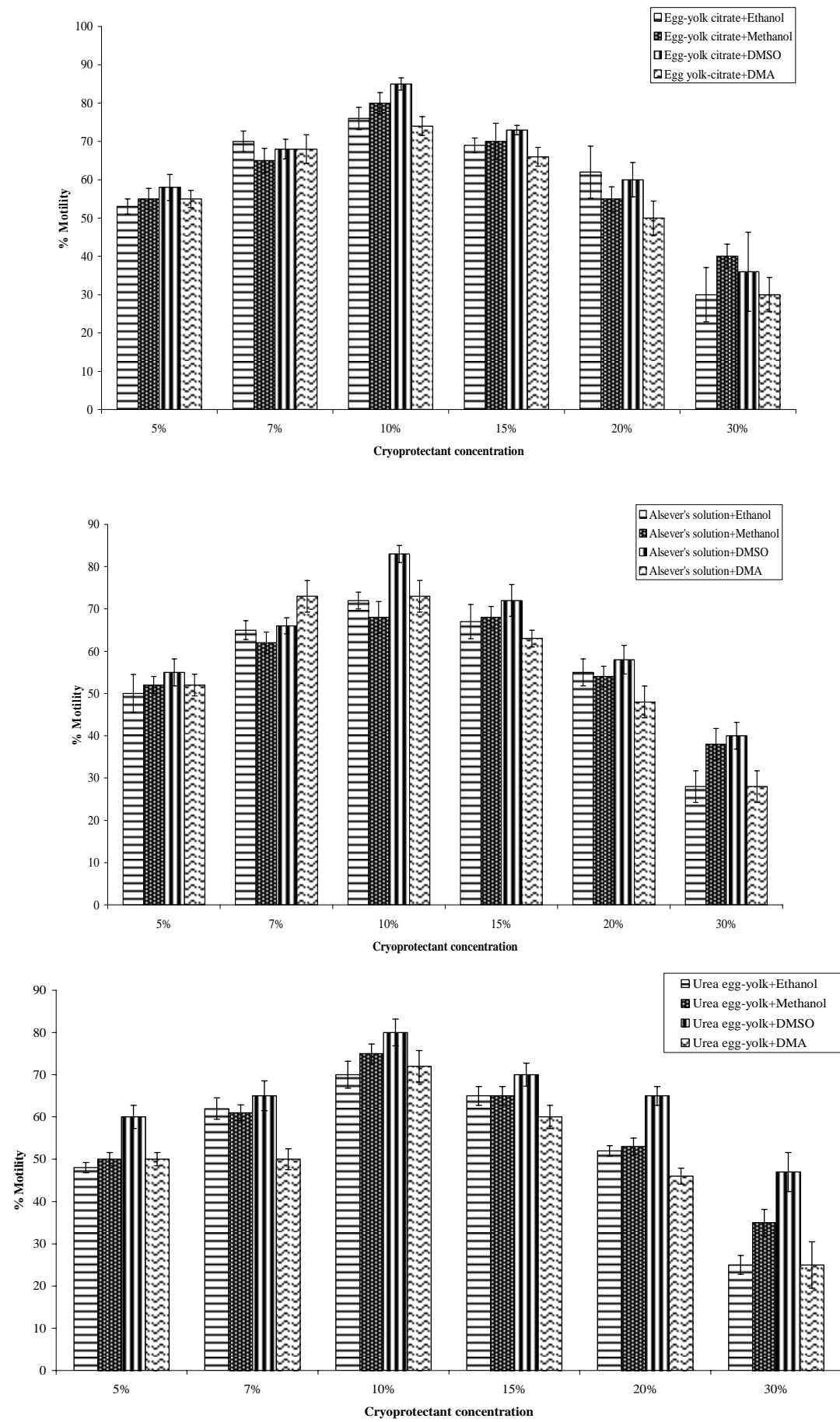

Fig. 2 a-c. The effects of cryoprotectant concentration on post-thaw motility of spermatozoa of $L$. rohita. Milt diluted with (a) egg-yolk citrate, (b) Alsever's solution and (c) urea egg-yolk 


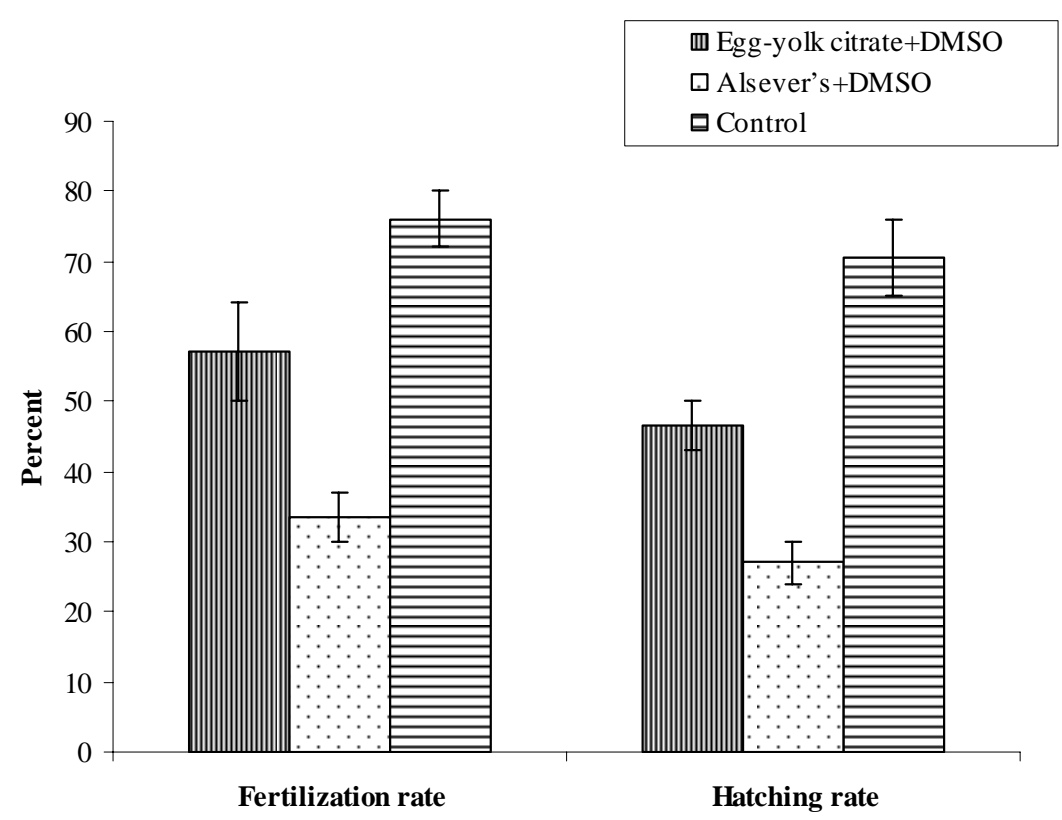

Fig. 3. Fertilization and hatching of eggs of L. rohita with cryopreserved and fresh sperm

\section{DISCUSSION}

Development of cryopreservation protocol of L. rohita demands standardization of few basic parameters. These are suitable combination of extender and cryoprotectant, optimum dilution ratio between milt and diluent, suitable concentration of cryoprotectant, and fertilization and hatching performance of cryopreserved sperm. The sperm cryopreservation protocol for different fish species seems variable and species-specific. Indian major carps are the main culture species in Bangladesh, India and Nepal but very little attention was paid to its cryopreservation. So far only two works have been reported on Indian major carp's sperm cryopreservation (Kumar, 1988 and 1989).

Six extenders (Alsever's solution, egg-yolk citrate, urea egg-yolk, Kurokura-2, $\mathrm{M}^{\mathrm{a}}, \mathrm{M}^{\mathrm{b}}$ ) and five cryoprotectants (methanol, ethanol, DMSO, DMA, glycerol) were used in the present study. The choice of the extenders was made from previous studies of Kumar (1988 and 1989) on Indian major carps and Linhart and Rodina (2000) on common carp. DMSO with egg-yolk citrate, Alsever's solution and urea egg-yolk performed best producing highest $(>80 \%)$ post-thaw motility. These results proved that the extenders might have an optimal osmolality to balance the osmotic pressure of spermatozoa. When egg-yolk citrate is used as extender it acts as an extracellular cryoprotectant. Egg-yolk citrate improves post-thaw motility because the low-density lipoprotein fraction (LDL) associates with cell membranes and provides protection against injury during the cryopreservation process (Babiak et al., 2001). Similarly, the Na-citrate fraction of Alsever's solution associated with cell membrane may provide protection against injury during freezing. Kumar (1989) 
reported satisfactory performance of Alsever's solution in preservation of Indian major carp sperm. A good result from Alsever's solution with 10\% DMSO for preservation of silver carp (H. molitrix) sperm was also reported (Alvarez et al., 2003).

Dilution of milt is another important factor for cryopreservation. Lahnsteiner (2000) proposed that the cell concentration in the extenders should not extend (2.0-3.0) $\times 10^{9}$ cells $/ \mathrm{ml}$ extender when sperm is frozen in straws. At the higher cell concentrations, the post-thaw fertility of milt significantly decreased, probably as a result of cell compression because of limited intracellular space. So, dilution of milt is essential and the extent of dilution often depends on the constituents of the extending media, concentration of the spermatozoa in gonad, the sperm physiology of the species and on the freezing protocols. Six ratios (1:2, 1:4, 1:7, 1:10, 1:15 and 1:20) were tested in the present study and 1: 4 dilution ratios was found best for the extenders egg-yolk citrate and urea egg-yolk, and that of 1:9 for Alsever's solution. These three dilutions were applied in the subsequent freezing trials. Bergeron et al. (2002) reported dilution of Walleye spermatozoa at the ratios (semen: extender) of 1:5, 1:9 and 1:15, and best results were obtained at 1:15. Dreanno et al. (1997) found no significant difference of post-thaw motility when turbot sperm was diluted at the ratios of 1:1, 1:2, 1:4 and 1:9. Rafiquzzaman et al. (2007) and Sarder et al. (2007) observed highest post-thaw motility of sperm of L. rohita and C. carpio respectively at 1:4 for egg-yolk citrate and urea egg-yolk and 1:9 for Alsever's solution.

Cryoprotectants are essential for the preservation of animal cell at low temperature and the choice of cryoprotectants often depends on the ability of permeation through cell membrane. In the present study, low molecular weight molecules were selected as cryoprotectant so that they could pass through the cell membrane easily. Among the five cryoprotectants, $10 \%$ ethanol with egg-yolk citrate and 10\% DMSO with the three extenders (egg-yolk citrate, urea egg-yolk and Alsever's solution) gave significantly $(\mathrm{P}<0.01)$ higher post-thaw motility than other cryoprotectants. DMA, methanol and ethanol also gave satisfactory post-thaw motility when they were mixed with the three extenders (egg-yolk citrate, urea egg-yolk and Alsever's solution) but these were significantly $(\mathrm{P}<0.01)$ less efficient than that of previous combination. Gwo et al. (1991) reported no significant $(\mathrm{P}<0.05)$ differences in post-thaw motility when $15 \%$ and $20 \%$ concentrations of DMSO were used to preserve Atlantic croaker spermatozoa. Poor postthaw motility was observed at $30 \%$ concentration level of all four different cryoprotectants. Similar assumption was postulated by Rana and McAndrew (1989) that the motility could not be initiated when the spermatozoa was suspended in $30 \%$ and $40 \%$ methanol or DMSO. DMSO has been considered as a common and effective cryoprotectant for cryopreservation of fish sperm (Lahnsteiner, 2000; Billard et al., 2004; Horvath et al., 2003 and Linhart et al., 2005) and cell lines (Zhang and Rawson, 2007). Sarder et al. (2007) observed best post-thaw motility of sperm of common carp (Cyprinus carpio) from $10 \%$ DMSO. When DMSO is used as cryoprotectant it penetrates rapidly into the cellular membrane (Rao, 1989) and brings a quick balance in between the intra and extra-cellular fluid concentration. Glycerol, on the other hand, exhibited worst performances in both equilibration and post- thaw motility and in most cases it produced a big clot. It might be happened due to its slow penetration into the cell membrane (Harvey and Ashwood- 
Smith, 1982). DMSO and glycerol at concentrations of 5\% and 20\% (v/v) have been widely used in cryopreservation of marine fish sperm but DMSO was superior to glycerol for sperm of yellow fin sea-bream, black grouper, barramundi and turbot (Gwo, 1993 and 1994; Palmer et al., 1993 and Dreanno et al., 1997). Though glycerol is well known as first used extender but there are also some indications that the presence of glycerol lowers the fertilizing ability of sperm in several fish species. Glycerol caused a total loss of motility of grouper E. tauvina spermatozoa (Withler and Lim, 1982) and appeared to be toxic to spermatozoa of pacific herring and turbot (Pillai et al., 1994 and Dreanno et al., 1997).

Successful fertilization and hatching of eggs using cryopreserved sperm is important for standardizing cryopreservation protocol. In this study, all the extenders and cryoprotectants were used for breeding trials but hatching was obtained from the sperm preserved with egg-yolk citrate plus DMSO and Alsever's solution plus DMSO. However, in both cases the fertilization and hatching rates were low and it was between 33-57\% and $27-46 \%$ respectively. Rana and McAndrew (1989) recorded mean fertilization rates ranging 38.7 to $93.4 \%$ of control after 13 months of storage of tilapia spermatozoa. The causes of variability of fertilization and hatching rates might be improper egg sperm ration of cryopreserved spermatozoa in the fertilization process or major cryoinjury during freezing or thawing process. Muchlisin et al. (2004) proposed the requirement of frozen spermatozoa for 15 times more than fresh sperm for obtaining sufficient fertility in rainbow trout

\section{CONCLUSION}

The preliminary attempts those were taken to develop protocol for cryopreservation of sperm of L. rohita seemed successful. Fertilization and hatching of eggs using cryopreserved sperm has been possible but further improvement is necessary. Although the cryopreservation protocol developed in the experiment is useful for conserving biodiversity of L. rohita, few points such as improvement of fertilization techniques, suitable egg sperm ratio, and feasibility of cryogenic gene banking need to be investigated.

\section{ACKNOWLEDGEMENTS}

Authors would like to thank Ministry of Science, Information \& Communication Technology, Government of People's Republic of Bangladesh and Bangladesh Agricultural University Research System (BAURES) for providing financial support to conduct this study.

\section{REFERENCES}

Alam, M. F. 2002. Socioeconomic aspects of carp production and consumption in Bangladesh. In: Penman, D. J., M. G., Hussain, B. J. McAndrew and M. A. Mazid (eds). Proc. Workshop on Genetic Management and Improvement Strategies for Exotic Carps in Bangladesh, BFRI, Mymensingh, Bangladesh, 83-89 pp. 
Alvarez, B., Fuentes, R., Pimentel, R., Abad, Z., Cabrera, E., Pimentel, E. and Arenal, A. 2003. High fry production rates using post-thaw silver carp (Hypophthalmichthys molitrix) spermatozoa under farming conditions. Aquaculture, 220: 195-201.

Ashwood-Smith, M. J. 1980. Low temperature preservation of cells, tissues, and organs. In: M. J. Ashwood-Smith and J. Farrant, (editors). Low temperature preservation in medicine and biology. Pittman Medical, Tunbridge Wells, Kent, UK. 19-44 pp.

Babiak, I., Glogowski, J., Goryczko, K., Dobosz, S., Kuzminski, H., Strzezek, J. and. Demianowicz, E. 2001. Effect of extender composition and equilibration time of fertilization ability and enzymatic activity of rainbow trout cryopreserved spermatozoa. Theriogenology, 56: 177-192.

Bergeron, A., Vandenberg, G., Proulx, D., and Bailey, J. L. 2002. Comparison of extenders, dilution ratios and theophylline addition on the function of cryopreserved Walleye semen. Theriogenology, 57: 1062-1071.

Billard, R., Cosson, J., Noveiri, S. B. and Pourkazemi, M. 2004. Cryopreservation and short term storage of sturgeon sperm. Aquaculture, 236: 1-9.

Day, F. 1878. The fishes of India being a natural history of the fishes known to inhabit the seas and freshwaters of India, Burma and Ceylon. London Wilham Dawson and Sons (pub.), p 778. (Reprinted 1958).

DoF, 2011. Fish Week Compendium, Department of Fisheries, Ministry of Fisheries and Livestock, Government of the People's Republic of Bangladesh, 136 p.

Dreanno, C., Suquet, M., Quemener, L., Cosson, J., Fierville, F., Normant, Y. and Billard, R. 1997. Cryopreservation of turbot (Scophthalmus maximus) spermatozoa. Theriogenology, 48 : 589-603.

Eknath, A. E. and Doyle, R. W. 1990. Effective population size and rate of inbreeding in aquaculture of Indian major carps. Aquaculture, 85: 293-305.

FAO. 2005. Tehnical paper on Genetic status of Indian Major Carps. FAO Database on Introductions of Aquatic Species (DIAS).

Gwo, J. C. 1993. Cryopreservation of block grouper (Epinephelus malabaricus) spermatozoa. Theriogenology, 39: 1331-1342.

Gwo, J. C. 1994. Cryopreservation of yellowfin seabrem (Acanthopagrus latus) spermatozoa (Teleost, Perciformis, Sparidae). Theriogenology, 41: 989-1004.

Gwo, J. C., Strawn, K., Longnecker, M. T. and Arnold, C. R., 1991. Cryopreservation of Atlantic Croaker spermatozoa. Aquaculture, 94: 355-375.

Hansen, M.M., Simonsen, V., Mensberg, K.-L. D., Sarder, Md. R. I. and Alam, Md. S. 2006. Loss of genetic variation in hatchery-reared Indian major carp, Catla catla. Journal of Fish Biology 69 (Supplement B):229-241.

Harvey, B. and Ashwood-Smith, M. J. 1982. Cryoprotectant penetration and supercooling in the eggs of salmonid fishes. Cryobiol., 19: 29-40. 
Horvath, A., Miskolczi, E. and Urbanyi, B. 2003. Cryopreservation of common carp sperm. Aquatic Living Resources, 16: 457-460.

Hossain, M. S., and Sarder, M. R. I. 2009. Cryogenic freezing of silver carp spermatozoa for conservation of gene pool. Progressive Agriculture, 20(1\&2): 99-106.

Kumar, K. 1988. A comparative study of various extenders for cryopreservation of carp sepermatozoa. Indian J. Anim. Sci., 58(11): 1355-1360.

Kumar, K. 1989. Studies on cryogenic preservation of carp spermatozoa In: Das and Jhingran (eds.). Fish Genetics in India, Today and Tomorrows Printers and Publishers, New Delhi., 199-206 pp.

Lahnsteiner, F. 2000. Semen cryopreservation in the Salmonidae and in the Northern pike. Aqua. Res., 31: 245-258.

Linhart, O. and Rodina, M. 2000. Cryopreservation of common carp (Cyprinus carpio) and Tench (Tinca tinca) sperm for gene resources conservation. Reprod. Physiol. Fish., 23: 402-404.

Linhart, O., Rodina, M., Flajshans, M., Gela, D. and Kocour, M. 2005. Cryopreservation of European catfish Silurus glanis sperm: sperm motility, viability, and hatching success of embryos. Cryobiology, 51: 250-261.

Magyary, I., Dinnyes, A. and Urbanyi, B. 2000. Cryopreservation methods for sperm of the common carp. In: cryopreservation in Aquatic species. Tiersch, T. R. and P. M. Mazik (eds.). World Aquaculture society, Baton Roige, Louisiana. pp. 288-289.

Muchlisin, Z. A., Hashim, R. and Chong, A. S. C. 2004. Preliminary study on the cryopreservation of tropical bagrid catfish (Mystus nemurus) spermatozoa; the effect of extender and cryoprotectant on the motility after short-term storage. Theriogenology, 62: 25-34.

Palmer, P. J., Black, A. W. and Garrett, R. N. 1993. Successful fertility experiments with cryopreserved spermatozoa of Barramundi, Lates calcarifer (Bloch), using dimethyl sulfoxide and glycerol as cryoprotectants. Reprod. Fert. Develop., 5: 285-294.

Pillai M.C., Yanagimachi, R. and Cherr, G. N. 1994. In vivo and in vitro initiation of sperm motility using fresh and cryopreserved gametes from Pacific herring, Clupea pallasi. J. Expt. Zool., 269: 62-68.

Rafiquzaman, S.M., Sarder, M.R.I., Islam, M.S. and Sultana, R. 2007. Sperm cryopreservation of rohu, Labeo rohita: cryodiluents, sperm:cryodiluents ratio and cryoprotectant concentratiion. Bangladesh J. Fish. Res., 11(2): 141-152.

Rana, K. J. and McAndrew, B. J. 1989. The viability of cryopreserved Tilapia spermatozoa. Aquaculture, 76: 335-345.

Rao, K. G. 1989. Cryopreservation of carp sperm. In: Das and Jhingran (eds.) Fish Genetics in India, Today and Tomorrows Printers and Publishers, New Delhi. 193-198 pp.

Sarder, M. R. I. 2004. Application of cryopreservation in the Indian major carps (Catla catla, Labeo rohita, Cirrhinus cirrhosus) and other culture species for their quality seed production. SUFER, DFID final Report, May 2004. 
Sarder, M. R. I., Salam, M.A. and Hussain, M. G. 2007. Effects of diluent, dilution and cryoprotectant concentration on frozen sperm of common carp (Cyprinus carpio L.). The Bangladesh Veterinarian, 24(1): 158-167.

Sarder, M. R. I., Rafiquzzaman, S. M. and Islam, M. F. 2009. Cryopreservation of spermatozoa of Mrigal, Cirrhinus cirrhosus with a view to minimize inbreeding and hybridization. Journal of Bangladesh Agricultural University, 7(1): 211-218.

Withler, F. C. and Lim, L. C. 1982. Preliminary observations of chilled and deep-frozen storage of grouper (Epinephelus tauvina) sperm. Aquaculture, 27: 389-392.

Zhang, T., and D. M. Rawson. 2007. Studies on cryopreservation of luc gene transfected bluegill sunfish fibroblast cell line. Cryoletter, 23: 191-196. 